\title{
ISLAM NUSANTARA (DESKRIPTIF-ANALITIS)
}

\author{
Ryandi \\ Universitas Islam Negeri Sumatera Utara (UINSU) Medan \\ ryanasofee@gmail.com
}

\begin{abstract}
Abstrak
Tulisan ini merupakan uraian deskriptif-analitis tentang Islam Nusantara (selanjutnya disebut IN), yang belakangan ini banyak diperbincangkan baik di kalangan elit intelektual, agamawan dan bahkan masyarakat awam. Dari sini dapat disimpulkan bahwa terdapat dua pemaknaan terhadap Islam Nusantara. Pertama merujuk pada praktik orang-orang Nusantara dalam ber-Islam, ini artinya secara implisit, makna tersebut berarti Islam di Nusantara, yang tentunya berbeda dengan orang-orang Islam di negaranegara Islam lainnya. Kedua, merujuk pada peleburan nilai-nilai Islam pada Nusantara dalam kerangka HAM, Demokrasi, Kearifan Lokal, dan Pancasila, tanpa memperhatikan aspek-aspek pokok atau tsawabit dalam Islam. Namun demikian, menurut penulis, walaupun pada pemaknaan pertama, maksud Islam Nusantara adalah baik, pengistilahan tersebut juga kurang tepat. Kata "Islam" adalah istilah kunci (key concept) yang tidak perlu ditambahi atau dikurangi. Penambahan kata dalam Islam tentunya mereduksi makna Islam itu sendiri.
\end{abstract}

Kata Kunci : Deskriptif-Analitis, Islam, Nusantara

\begin{abstract}
This paper is a descriptive-analytical description of Nusantara Islam (hereinafter referred to as IN), which has recently been much discussed among both the intellectual elite, religious leaders and even ordinary people. From this it follows that there are two meanings of Nusantara Islam. The first refers to the practice of Archipelago people in Islam, this means implicitly, the meaning means Islam in the Archipelago, which is certainly different from the Muslims in other Islamic countries. Second, it refers to the fusion of Islamic values in the archipelago within the framework of human rights, democracy, local wisdom, and Pancasila, without regard to the basic aspects or tsawabit in Islam. However, according to the writer, although in the first meaning, the meaning of Nusantara Islam is good, the terminology is also not quite right. The word "Islam" is a key concept (key concept) that does not need to be added or subtracted. The addition of words in Islam certainly reduces the meaning of Islam itself.
\end{abstract}

Keywords: Descriptive-Analytical, Islam, Nusantara

\section{Pendahuluan}

Tulisan ini merupakan uraian deskriptif-analitis tentang Islam Nusantara (selanjutnya disebut IN), yang belakangan ini banyak diperbincangkan baik di kalangan elit intelektual, 
agamawan dan bahkan masyarakat awam. Uraian deskriptif meliputi latar belakang kemunculan IN, makna yang dimaksud oleh para penggagasnya.

Uraian tersebut kemudian dianalisis menggunakan pendekatan manthiq, dari aspek jami' (universalitas) dan mani' (diferensiasi)-nya. Pendekatan ini lazim digunakan oleh para Fuqoha' dalam menilai (value judgment) sebuah fakta. Perlu dicatat, bahwa pendekatan ini tidak hanya bergerak pada segi koherensi teks tetapi juga korespondensinya dengan fakta di lapangan dan dampak sosial-keagamaan yang ditimbulkan.Dari sini kemudian dapat dibuat turunan hukum sebenarnya dari IN.

\section{Tinjauan Deskriptif Islam Nusantara: Latar Belakang dan Makna}

Sebelum menjelaskan lebih jauh tentang apa itu Islam Nusantara, berikut akan dijelaskan terlebih dahulu latar belakang kemunculan istilah tersebut, sebab dalam teori "Sejarah Ilmu", sebuah istilah, teori atau konsep tidaklah lahir dari ruang kosong (vaccum history)(Muhammad Mushlih, 2008 : 9). Secara historis, istilah Islam Nusantara diwacanakan secara resmi oleh elit NU pada pra-Mu'tamar ke-33 NU dengan tema: "Islam Nusantara sebagai Islam Mutamaddin Menjadi Tipe Ideal Dunia Islam". Jika ditelisik, terdapat dua kemungkinan mengapa istilah ini muncul:

1) Respon terhadap dua kelompok yang saling bertentangan: pertama, fundamentalis yang memaknai Islam sebagai rahmatan lil 'alamin secara literal. Dalam pemahaman mereka, Islam adalah apa-apa yang dipraktikkan oleh Nabi Muhammad Saw. Budaya apa saja yang tidak pernah dipraktikkan pada zaman Nabi, bukan bagian dari Islam. Kedua, kelompok substantif yang memaknai universiltas ajaran Islam tidak terbatas ruang dan waktu, sehingga mampu masuk ke budaya apapun. Dalam konteks ini, local-wisdom atau kearifan lokal diapresiasi terlalu berlebih, bahkan sampai melampaui batas-batas yang pokok (tsawabit) dalam Islam. Kelompok pertama cenderung eksklusif, sedangkan kelompok kedua cenderung distortif(Khabibi Muhammad Luthfi, $2016: 2$ ).

2) Maraknya isu radikalisme, islamophobia, dan Arab spring (الثورات العربية). IN hadir untuk menginformasikan kepada dunia bahwa Islam yang ada di Indonesia, bukanlah islam yang keras, bukanlah Islam Arab melainkan Islam yang toleran, sopan dan penuh toleransi. Identitas ini dipertegas oleh presiden Republik Indonesia, Joko Widodo dalam forumforum regional dan internasional: "Alhamdulillah, Islam Kita Islam Nusantara, Islam yang penub sopan santun, penub tata krama dan toleransi”. Penegasan identitas ini bisa jadi berasal dari elit intelektual yang kemudian disambut baik oleh Pemerintah karena sesuai dengan agenda 
"moderasi Islam" atau bisa jadi permohonan pemerintah kepada elit intelektual untuk mewacanakan sebuah istilah yang menunjukkan identitas ke-Islaman Indonesia yang khas, yang berbeda dari ummat Islam lainnya di dunia(Mohammad Guntur Romli, 2016 : 17).

Lalu, apa yang dimaksud dengan Islam Nusantara? Secara bahasa istilah ini terdiri dari dua kata: Islam dan Nusantara. Islam merujuk pada agama yang dibawa oleh Nabi Muhammad Saw. Sedangkan Nusantara merujuk pada wilayah kepulauan dari sabang sampai Merauke. Namun, dalam pemaknaannya, para penutur Islam Nusantara memiliki perbedaan.

Pertama, Islam Nusantara merujuk pada corak ke-Islaman yang dipraktikkan oleh ummat Islam di wilayah Nusantara. Ini dapat dilihat dari penuturan beberapa elit intelektual berikut.

Islam Nusantara itu adalah Islam Nusantara yang empirik dan distingtif sebagai hasil interaksi, kontekstualisasi, indigenisasi, penerjemahan, vernakularisasi Islam universal dengan realitas sosial,budaya, dan sastra di Indonesia," (Oman Fathurrahman, guru besar Filologi Islam UIN Jakarta)

"istilah "IslamNusantara" memang agak ganjil didengar lantaran Islam memang sumbernya satu dan bersifat ilahiyah. Tapi, ...harus diperhatikan bahwa Islam juga terealisasi dalam praktik keseharian. Artinya, selain ilahiyah, Islam juga bersifat insaniyah (manusiawi). ...karena itu, maka ada juga fiqih Nusantara. "Fiqih Nusantara adalah paham dan prespektif keislaman di bumi Nusantara sebagai hasil dialektika teks-teks syariat dan budaya, juga realitas di (daerah) setempat,"...adanya pemahaman kontekstual terhadap teks suci dengan mempertimbangkan adat lokal (urf) demi kemaslahatan tak hanya dari segi ukhrawi tapi juga duniawi. (KH. Afifuddin Muhajir, Katib Syuriah PBNU)

Kedua, Islam Nusantara merujuk pada cara pandang Nusantara (Nusantara worldview) dalam berislam.Hal ini sebagaimana ditegaskan oleh Mohammad Guntur Romli dan Tim Ciputat School dalam Islam Kita, Islam Nusantara(Mohammad Guntur Romli : 2016).

"Islam Nusantara" memiliki perbedaan dari "Islam di Nusantara". Nusantara pada istilah yang pertama adalah sifat, dalam bahasa pesantren disebut "mudhafun ilaihi"-ia mensifati kata Islam, dalam istilah lain, "Islam Nusantarawi". Sedangkan istilah kedua: Islam di Nusantara hanya menunjukkan Nusantara hanya sebagai tempat saja yang tidak memiliki hubungan, apalagi pengaruh terhadap Islam. Oleh karena itu "Islam Nusantara" bisa dipahami Islam dengan corak, warna, kekhasan, keunikan, karakter, budaya Nusantara. Lantas, apa Nusantara itu? Di sini Nusantara tidak menunjuk pada satu model, corak, budaya, namun menunjuk pada keragaman yang ada di pulau-pulau Nusantara. Karena Nusantara merupakan kumpulan dari pulau-pulau, yang tidak kurang dari 17.000 pulau. Nusantara adalah nama yang pernah diajukan oleh Ki Hajar Dewantara untuk menyebut wilayah Indonesia masa kini. Nusantara yang disebut Mpu Prapanca dalam Kakawin Nagarakretagama sebagai wilayah kekuasaan Kerajaan Majapahit meliputi Jawa, Sumatra, Semenanjung Malaya, Borneo, Sulawesi, kepulauan Nusa Tenggara, Maluku, Papua, dan sebagian kepulauan Filipina. Maka, Nusantara bukan Jawa, malah Nusantara dari nama aslinya: "nusa" (pulau) "antara" (lain/seberang) yakni pulau-pulau di seberang Jawa. Penyebutan Nusantara ini 
pula yang terkait dengan Kerajaan Majapahit untuk mengingatkan kita akan kebesaran masa lalu bangsa ini. Bangsa yang besar dan pernah berjaya.

Lebih jauh, mereka menyusun lima nilai dasar Islam Nusantara(Mohammad Guntur Romli : 2016).

1. Kami memahami Muslim sebagai identitas kolektif atas siapapun yang menganggap dirinya Muslim yang meyakini Allah Swt sebagai satu-satunya Tuhan dan Nabi Muhammad Saw sebagai Rasul (utusan) Allah Swt, terlepas dari perbedaan tafsir atas agama Islam. Mengenai perbedaan tafsir itu, kami berpandangan biarlah itu urusan individu yang bersangkutan dengan Tuhannya, yang tak patut diintervensi oleh negara atau pihak lain.

2. Kami memperjuangankan nilai esensial Islam yang tidak mendiskriminasi manusia baik atas dasar suku, gender, ras, disabilitas, paham agama, dan sebagainya. Kami menolak segala bentuk kebencian baik yang berwujud ucapan (hate speech), tulisan dan tindakan terhadap suku, gender, ras, disabilitas, agama, aliran, paham keagamaan apapun, karena bertentangan dengan nilai-nilai esensial Islam.

3. Berbagai hal yang bertentangan dengan prinsip hak-hak asasi manusia (HAM) maka potensial bertentangan pula dengan nilai-nilai esensial Islam yang kami yakini.

4. Berbagai hal yang bertentangan dengan prinsip-prinsip demokrasi dan kearifan lokal di Nusantara, maka potensial bertentangan pula dengan nilai-nilai esensial Islam yang kami yakini.

5. Berbagai hal yang bertentangan dengan Pancasila dan pilar-pilar keindonesiaan, maka potensial bertentangan pula dengan nilai-nilai esensial Islam yang kami yakini.

\section{Tinjauan Analitis Islam Nusantara:Maqhosid dan Tahafut}

Untuk menganalisis pewacanaan Islam Nusantara, akan digunakan pendekatanmantiqiy (logika), yaitu melihat pendefinisian "Islam Nusantara" dari aspek jami' (universalitasnya) dan mani' (diferensiasinya), baru kemudian dibuat turunan hukumnya. Pendekatan ini lazim digunakan oleh para Fuqoha' dalam menghasilkan sebuah hukum. Perlu dicatat, bahwa pendekatan ini tidak hanya bergerak pada segi koherensi teks tetapi juga korespondensinya dengan fakta di lapangan dan dampak sosial-keagamaan yang ditimbulkan. 
Jika dilihat dengan pendekatan manthiqi, pemaknaan Islam Nusantara oleh kelompok pertama sebagaimana dijelaskan tidaklah bermasalah. Sebab, hanya merujuk pada praktik orangorang Nusantara dalam ber-Islam, ini artinya secara implisit, makna tersebut berarti Islam di Nusantara, yang tentunya berbeda dengan orang-orang Islam di negara-negara Islam lainnya.

Hal ini disebabkan oleh sosio-kultural masyarakat yang berbeda-beda. Pada konteks ini, penggagas Islam Nusantara ingin menegaskan bahwa Islam bersifat waqiizyah (kontekstual), dimana dalam perkembangannya sangat memperhatikan tradisi, kondisi sosiokultural, dan tempat masyarakat sebagai objek dan sekaligus subjek hukum. Dalam hal ini, Islam memiliki konsep al-urf ataual-'adah, merujuk pada kebiasaan yang dilakukan oleh masyarakat, dan bisa dijadikan sebagai pijakan hukum. Ke-hujjiyahan al-'Urf terdapat pada al-Qur'an(QS: al-A'raf: 199), Hadits, Ijma’dan dalil ‘aqliy.

Namun perlu dicatat, dalam pengambilan al-Urf perlu dilihat aspek keabsahannya ditinjau dari syari'at. Sebab, dalam konteks sosial, terdapat budaya-budaya yang berlawanan dengan syari'at, inilah yang disebut dengan al-Urf al-Fasidah (invalid custom). Ini dilihat dari karakteristiknya, menghalalkan yang haram atau membatalkan yang wajib. Dalam konteks Nusantara, pertandingan sabung ayam, larung sajen di laut Kidul untuk mendapatkan keberakahan laut dan lain sebagainya tidaklah dapat dijustifikasi sebagai al-'Urf, dan menjadi bagian Islam Nusantara. Lain halnya dengan pemakaian batik, blankon, sikap ramah tamah dan lain sebagainya, merupakan budaya Nusantara yang tidak mengganggu prinsip-prinsip Islam. Inilah yang disebut sebagai al-Urf al-Shahih (valid custom).

Berbeda dengan yang pertama, pada kelompok kedua, pemaknaan Islam Nusantara, lebih kepada pencorakan Islam kepada Nusantara, dan cenderung bersifat politis (lih: poin 2-5). Ini dapat dilihat dari lima prinsipnya yang terkait dengan penegakan HAM, prinsip-prinsip demokrasi dan kearifan lokal, serta pancasila dan pilar-pilar ke-Indonesiaan. Dari sini muncul berbagai pertanyaan: Apakah HAM, dan demokrasi bagian dari Nusantara? Bukankah istilah tersebut berasal dari Barat? Sejauh mana garis demarkasi "bertentangan dengan HAM, demokrasi, Pancasila, dan kearifan lokal"secara potensial bertentangan dengan "nilai-nilai esensial Islam yang kami yakini'?Lantas, mana yang lebih didahulukan jika pada HAM, demokrasi, dan kearifan lokal dipandang baik, sementara dalam Islam dipandang buruk?

Lebih jauh, dari penelusuran penulis, terdapat fakta-fakta sebagai jawaban terhadap pertanyaan-pertanyaan tersebut:

Pertama, HAM dan Demokrasi yang mereka maksud bukanlah budaya atau al'‘ Urf masyarakat Islam Nusantara, namun berasal cara pandang Barat (western worldview). Ini dapat 
dilihat dari rekonstruksi mereka terhadap kebebasan beragama dengan paradigma teologi inklusif. Jika ditelisik lebih jauh, paradigma ini sejatinya berasal dari Anonymous Christian (Kristen Anonim) Karl Rahner, seorang teolog Katolik asal Jerman.

Konsep Rahner tentang Kristen Anonim telah memberikan pengaruh luas dan merupakan konsep inklusivisme Katolik, yang diadopsi secara resmi oleh Vatikan dan dideklarasikan dalam Konsili Vatikan II tahun 1962-1965. Dengan teori Kristen Anonim Rahner mencoba menampilkan wajah kristen yang simpatik kepada agama-agama lain. Ia menyatakan bahwa satu-satunya jalan keselamatan tidak lagi mutlak milik Gereja. Keselamatan juga ada di luar Gereja, karena ‘Anugerah' Yesus Kristus juga berlangsung dalam agama-agama lain. Artinya menurut teori tersebut, mereka bisa dikatakan sudah menjadi Kristiani tanpa nama Kristiani. Mereka adalah umat Kristiani Anonim.

Dalam konteks Islam Nusantara yang mereka gagas dinyatakan (Mohammad Guntur Romli : 2016).

"Al-Quran mengakui daya penyelamat agama-agama di luar Islam. Allah meminta penganut agama-agama lain konsisten pada keyakinan mereka, menjalankan aturan dan syariat mereka, tanpa penyelewengan. Secara eksplisit Al-Quran menyebutkan empat macam agama yang dijamin keselamatannya: Islam, Yahudi, Kristen dan Shabiin. Dalam surat Al-Baqarah (2) ayat 62 disebutkan:

"Sungguh, mereka yang beriman (Islam), mereka yang menganut agama Yabudi, orang Kristen dan Shabiin, siapa saja yang beriman pada Allab dam Hari Akbir, serta melakukan kebaikan, bagi mereka ada pabala pada Allah, tiada mereka perlu dikuatirkan dan tiada mereka berduka-cita".

Mayoritas Ahl tafsir mengartikan Sabi'in sebagai kaum penyembah bintang. Tentu saja bintang sekadar simbol yang merujuk pada Tuhan sebagai punca-ibadah. Namun, Ibn Jarir Al-Thabarî dalam tafsirnya, Jâmi’ al-Bayân mengutip sebuah pendapat: Sabi'in adalah orang yang berpindah-pindah agama untuk mencari Kebenaran. Jika penyembah bintang saja diberi jaminan keselamatan, maka, agama-agama lain yang memiliki keimanan terhadap Tuhan lebih berhak mendapat jaminan keselamatan tersebut.

Oleh karena itu agama dan kepercayaan yang diakui tidak terbatas pada agama dan kepercayaan yang disebutkan secara eksplisit oleh Al-Quran. Para ulama klasik dan penguasa terdahulu mengiaskan agama dan kepercayaan dengan agama dan kepercayaan yang disebutkan Al-Quran itu. Ada tiga "kategori" penting untuk agama yang disebutkan keselamatannya, yakni (1) percaya pada Tuhan (2) percaya pada Hari Akhir, yang merupakan Hari Perhitungan, Hari Pembalasan (3) melakukan 
kebaikan. Prinsip pluralitas jalan keselamatan itu dari surat Al-Baqarah ayat 62 dipertegas kembali dengan narasi yang hampir sama dalam surat Al-Mâ'idah (5) ayat 69.”

Kedua, kearifan lokal yang mereka maksud lebih dari sekedar pengakuan namun kepada pembenaran, dan perawatan, walaupun bertentangan dengan ajaran Islam. Ini dapat dilihat dari pernyataan salah seorang penggagas Islam Nusantara(Kholili Hasbi, 2015 : 16).

"Kalau dikumpulkan ya kelompok-kelompok dari aliran kepercayaan macammacam itu sebetulnya yang mewarisi Islam Nusantara. Saya lama meneliti golongan kebatinan yang beraneka ragam. Karena mereka memiliki traidisi yang sama, tradisi kebudayaan dan keyakinan yang sama pula"

Dari sini dapat disimpulkan bahwa apa yang mereka maksud dengan Islam Nusantara adalah peleburan nilai-nilai Islam pada Nusantara dalam kerangka HAM, Demokrasi, Kearifan Lokal, dan Pancasila, tanpa memperhatikan aspek-aspek pokok atau tsawabit dalam Islam. Hal ini kemudian menuntut penafsiran ulang terhadap ajaran Islam baik dari aspek teologi agar sesuai dengan kerangka ke-Nusantaraan.

Lebih jauh, walaupun pada kelompok pertama, maksud Islam Nusantara adalah baik, pengistilahan tersebut juga kurang tepat. kata "Islam" adalah istilah kunci (key concept) yang tidak perlu ditambahi atau dikurangi. Penambahan kata dalam Islam tentunya mereduksi makna Islam itu sendiri. Dalam sebuah kaidah disebutkan (الاسلام يعلو ولا يعلى عليه): Islam itu tinggi dan tidak ada yang lebih tinggi darinya. Penambahan ini tentunya menjadi aneh didengar seperti kata "orang", akan tereduksi jika ditambahi "utan" menjadi "orang utan". Pandangan ini didasarkan pada asumsi bahwa setiap terminologi kunci mengandung sebuah paradigma (Syed Naquib al-Attas, 1993 : 198).

Pengkategorian Islam Nusantara ke dalam al-mudhof wa al-mudhof ilaibi, tentunya problematis, sebab Islam adalah universal sedangkan Nusantara adalah partikular. Ini artinya Islam harus sesuai dengan Nusantara. Sementara sejarah membuktikan Islam dalam dialektikanya dengan tradisi Nusantara membentuk tiga sikap, yaitu: 1) tahmil (adoptive-compelent), 2) tahrim (destructive), 3) Taghyir (adoptive-reconstructive). Ini artinya dialektika yang dilakukan adalah penyesuaian tradisi dengan framework Islam, atau dengan kata lain mengislamkan Nusantara (Al-Ma'arif, 2015 : 271-273).

Dampak yang juga harus diperhatikan adalah bahwa penggunaan kata sifat pada Islam seperti halnya Islam Nusantara memberi kesan bahwa Islam itu plural. Pandangan demikian menurut al-Attas sejatinya berasal dari pengalaman Orientalis dalam mendistorsi makna Islam. 
....Al-Attas insists that there is no such thing as a Malaysian Islam that is distinct from other kinds of Islam. There are only different levels of intelligence....that any local variation in the practice, experience or understanding of Islam is due to Orientalist distortion, which be admits was not always intentional or malicious. Indeed, al-Attas is emphatic is ascribing misrepresentations of Islam to the Orientalists, poistivists, secularists, post-modernits, and social scientists, all of whom distort and diminish Islam"(Ziauddin Sardar \& Robin YassinKassab, 2013 : 127).

Poin penting yang perlu diambil dari sini adalah bahwa perbedaan ummat Islam hanya sebatas pada perbedaan tingkat intelektual penganutnya, bukan Islam itu sendiri. Hal inilah yang menghasilkan perbedaan mazhab, aliran pemikiran dan lain-lain.

\section{Penutup}

Dari sini dapat disimpulkan bahwa terdapat dua pemaknaan terhadap Islam Nusantara. Pertamamerujuk pada praktik orang-orang Nusantara dalam ber-Islam, ini artinya secara implisit, makna tersebut berarti Islam di Nusantara, yang tentunya berbeda dengan orang-orang Islam di negara-negara Islam lainnya. Hal ini disebabkan oleh sosio-kultural masyarakat yang berbedabeda. Pada konteks ini, penggagas Islam Nusantara ingin menegaskan bahwa Islam bersifat waqi'iyah (kontekstual), dimana dalam perkembangannya sangat memperhatikan tradisi, kondisi sosiokultural, dan tempat masyarakat sebagai objek dan sekaligus subjek hukum.

Kedua, merujuk pada peleburan nilai-nilai Islam pada Nusantara dalam kerangka HAM, Demokrasi, Kearifan Lokal, dan Pancasila, tanpa memperhatikan aspek-aspek pokok atau tsawabit dalam Islam. Namun demikian, menurut penulis, walaupun pada kelompok pertama, maksud Islam Nusantara adalah baik, pengistilahan tersebut juga kurang tepat. kata "Islam" adalah istilah kunci (key concept) yang tidak perlu ditambahi atau dikurangi. Penambahan kata dalam Islam tentunya mereduksi makna Islam itu sendiri.

\section{Daftar Pustaka}

Abdullah Ibn Yusuf Abu Muhammad al-Hanafi az-Zaila'iy, Nash bar-Raayah, (Cairo Daar alHadits, $1357 \mathrm{H}$ )

Abu Ishâq asy-Syâtibiy, al-Muwâfaqât, (Cairo, al-Maktabah at-Taufîqiyyah, tt)

Al-Ma'arif, Islam Nusantara: Studi Epistemologis dan Kritis, (Analisis: Jurnal Studi Keislaman, Vol. 15, No. 2, Desember 2015)

Critical Muslim 07: Muslim Archipelago, ed. Ziauddin Sardar and Robin Yassin-Kassab, (London: Hurst Publisher, 2013)

Khabibi Muhammad Luthfi, Islam Nusantara: Relasi Islam dan Budaya Lokal, (Shahih, Vol. 1, Nomor 1, Januari-Juni 2016) 
Kholili Hasbi dkk, Islam Nusantara: Islamisasi Nusantara atau Menusantarakan Islam?, (tanpa tempat, 2015)

Mohammad Guntur Romli dkk, Islam Kita Islam Nusantara, (Ciputat School, Cet. 1, 2016)

Muhammad Ibn 'Ali asy-Syaukani, Nailul Awthar, ditahqiq oleh Dr. Nasr Farid Muhammad Washil, (Cairo, al-Maktabah at-Taufiqiyyah, tth)Vol. VI

Muhammad Mushlih, Filsafat Ilmu: Kajian atas Asumsi Dasar Paradigma dan kerangka Teori Ilmu Pengetahuan, (Yogyakarta: Belukar, Cet. V, 2008)

Syed Naquib al-Attas, Islam and Secularism, (Kuala Lumpur: ISTAC, 1993) 